IZA DP No. 6463

The Intergenerational Persistence of Human Capital: An Empirical Analysis of Four Generations

Mikael Lindahl Mårten Palme Sofia Sandgren Massih Anna Sjögren

April 2012 


\title{
The Intergenerational Persistence of Human Capital: An Empirical Analysis of Four Generations
}

\author{
Mikael Lindahl \\ Uppsala University, CESifo, IFAU, UCLS and IZA \\ Mårten Palme \\ Stockholm University and IZA \\ Sofia Sandgren Massih \\ Uppsala University \\ Anna Sjögren \\ IFAU and SOFI, Stockholm University \\ Discussion Paper No. 6463 \\ April 2012 \\ IZA \\ P.O. Box 7240 \\ 53072 Bonn \\ Germany \\ Phone: +49-228-3894-0 \\ Fax: +49-228-3894-180 \\ E-mail: iza@iza.org
}

\begin{abstract}
Any opinions expressed here are those of the author(s) and not those of IZA. Research published in this series may include views on policy, but the institute itself takes no institutional policy positions.

The Institute for the Study of Labor (IZA) in Bonn is a local and virtual international research center and a place of communication between science, politics and business. IZA is an independent nonprofit organization supported by Deutsche Post Foundation. The center is associated with the University of Bonn and offers a stimulating research environment through its international network, workshops and conferences, data service, project support, research visits and doctoral program. IZA engages in (i) original and internationally competitive research in all fields of labor economics, (ii) development of policy concepts, and (iii) dissemination of research results and concepts to the interested public.
\end{abstract}

IZA Discussion Papers often represent preliminary work and are circulated to encourage discussion. Citation of such a paper should account for its provisional character. A revised version may be available directly from the author. 


\section{ABSTRACT}

\section{The Intergenerational Persistence of Human Capital: An Empirical Analysis of Four Generations}

Most previous studies of intergenerational transmission of human capital are restricted to two generations - parents and their children. In this study we use a Swedish data set which enables us link individual measures of lifetime earnings for three generations and data on educational attainments of four generations. We investigate to what extent estimates based on income data from two generations accurately predicts earnings persistence beyond two generations. We also do a similar analysis for intergenerational persistence in educational attainments. We find two-generation studies to severely under-predict intergenerational persistence in earnings and educational attainment over three generations. Finally, we use our multigenerational data on educational attainment to estimate the structural parameters in the Becker-Tomes model. Our results suggest a small or no causal effect of parental education on children's educational attainment.

JEL Classification: D31, J62

Keywords: intergenerational income mobility, human capital transmission, multigenerational income mobility

Corresponding author:

Mårten Palme

Department of Economics

Stockholm University

SE-106 91 Stockholm

Sweden

E-mail: Marten.Palme@ne.su.se

\footnotetext{
* We thank Anders Björklund, Susan Dynarski, Peter Fedriksson, Björn Öckert as well as seminar participants at Uppsala, SOFI (Stockholm University), Trondheim, the CESifo 2011 meeting in Munich, the 2011 Nordic Summer Institute in Labor Economics at the Faroe Islands and the Conference on the Economics of the Family (INED) in Paris 2011 for valuable comments on previous drafts and Eskil Forsell, Erika Karlenius and Arvid Olovsson for excellent research assistance. Special thanks to Adrian Adermon for help with the data construction and programming. Mikael Lindahl is a Royal Swedish Academy of Sciences Research Fellow supported by a grant from the Torsten and Ragnar Söderberg Foundation, the Scientific Council of Sweden and the European Research Council [ERC starting grant 241161]. Mårten Palme gratefully acknowledges financial support from the Swedish Council of Social Research. Swedbank has provided financial support for the construction of the dataset.
} 


\section{Introduction}

Although most families have close connections with their grandparent or even greatgrandparent generations and most individuals would admit strong influences and transmission of different resources beyond their parent generation, economic analysis of intergenerational links is almost exclusively concerned with the relation between the parent and child generations. Dynamic macroeconomic models of human and physical capital investments, fertility and inequality, as well as models of cultural transmission, focus on the link between two consecutive generations (Diamond, 1965, Becker, Murphy and Tamura, 1990, Galore and Zeira, 1993, Bisin and Verdier, 2000, Mulligan, 1997, and Saez-Marti and Sjögren, 2008). Moreover, empirical studies on intergenerational income mobility, as surveyed in Solon (1999) and Black and Devereux (2010), are with few exceptions restricted to two generations. ${ }^{1}$ The Becker-Tomes model - the by far most important model for intergenerational transmission of human capital - relates financial and other resources of the parent generation to the outcome of the child generation.

The fact that generations beyond the parent generation influence individual outcomes has important implications for how we view income inequality at a given point in time, as well as how we interpret intergenerational transmission of human capital. Income inequality in a mobile society is commonly regarded as more justifiable since an individual's relative economic position is to a larger extent linked to the individual's own choices and economic performance, rather than inheritance from previous generations. A frequently cited example, as in Borjas (2009), is based on an initial income difference on 20 percent between two families. If there is an intergenerational correlation on 0.3 , we expect only 30 percent of this difference, or 6 percentage points, are expected to remain in the second generation. In the third generation, the difference is almost entirely eliminated, since only 1.8 percent is expected to remain. However, this example relies critically on the assumption that the intergenerational transmission process of human capital has a memory of only one period. If this is not the case, income convergence will take longer.

Extensions of the empirical analysis of intergenerational transmission of human capital beyond two consecutive generations relate to at least two additional strands in the literature on

\footnotetext{
1 Examples of some studies that focus on estimating the relationship between outcomes (education or occupation) for grandparents and grandchildren are Behrman and Taubman (1985), Maurin (2002), Sacerdote (2004, 2005), Sauder (2006) and Warren and Hauser (1997).
} 
equality of opportunity and socio-economic mobility across generations. First, as pointed out in Solon (1999) or Björklund et al. (2010), the "explained" variation in models based on siblings correlations is in general much higher than in models based on intergenerational correlations (around 0.3 compared to around 0.1). A plausible interpretation of this difference is that siblings share more characteristics than just parents. The potential influence of grandparents - and great-grandparents - is obviously one of these characteristics in addition to the influence of neighborhoods during adolescence, schools, and other environmental factors that siblings in most cases share, which may affect their economic position as adults. Second, extension of the analysis of intergenerational transmission beyond two generations relates to a recent literature which, following Roemer (1993), aims to measure the degree of equality of opportunity; see e.g. Aaberge et al. (2010) or Björklund et al. (2012). Generations beyond the parental generation constitute an obvious "circumstance" that may influence the economic position of the child generation in addition to the investment decisions and endowments of the parent generation, as suggested in the Becker-Tomes model.

In this paper, we investigate whether there are independent effects of the grandparent and the great-grandparent generation in the intergenerational transmission of human capital. Is the AR(1) process used in most studies on intergenerational income mobility sufficient to describe the income process across generations and to predict the income distribution for future generations? To answer this question, we use an exceptional data set containing measures of lifetime earnings for three consecutive generations and data on educational attainments for four generations. The data set is based on a survey of all third graders in Sweden's third largest city, Malmö, and its suburbs, in 1938. This index generation has subsequently been followed until retirement and information on parents, spouses, children and grandchildren have been added. The first generation was, on average, born in the late nineteenth century and the fourth generation typically completed their education in the early twenty-first century. Altogether there are 901 complete families, i.e., families where education data are available on at least one individual in each of four consecutive generations.

The empirical analysis is carried out in two steps. First, we estimate AR(1) models using OLS to investigate whether or not the analysis based on data from two consecutive generations can predict the correlations between the incomes of the child and grandparent generations for lifetime income and between the child and the great-grandparent generations for educational attainments. We explore heterogeneity in the intergenerational links in different parts of the income and educational distribution using transition matrices. We conclude that grandparents and even great-grandparents influence child earnings and 
education more than predicted by the correlation between two consecutive generations. In fact, the earnings correlation across three generations is more than 70 percent larger than predicted by the consecutive two-generation earnings correlations and the correlation in educational attainments across four generations is almost three times larger than predicted from the three consecutive generation correlations.

As a second step, we estimate the structural intergenerational parameters in the BeckerTomes model. We use great-grandparent generation educational attainments as instrumental variable for parent education. This approach was suggested already in Becker and Tomes (1986), but due to lack of data on four generations, has never been implemented. The identifying assumption is that there is no direct effect of great-grandparents on the outcome of the child, conditional on the grandparental and parental outcomes. We believe this assumption to be credible since it is rare for great-grandparents to meet and interact with their greatgrandchildren. Our results suggest no causal effect of parental education on childrens' educational attainment, conditional on intellectual, cultural and genetic transmission. This is in line with previous findings from recent studies based on outcomes from compulsory school reforms, twins and adoption data (see e.g. Holmlund, Lindahl and Plug, 2011, or Black and Devereux, 2010, for overviews).

At first sight, the results from the two parts of our empirical analysis may seem contradictory. Our first results tell us that mean reversion in intergenerational association in both educational attainments and labor earnings takes more time than was previously known from studies on two consecutive generations. Our second set of results suggests an insignificant effect of parental education on the educational attainments of the offspring. However, taken together, our results suggest that the intergenerational transmission of factors that we cannot directly measure - such as genetic, cultural or social factors - is significant and lasts more than two generations.

The paper proceeds as follows. In Section 2 we introduce the data set, discuss the construction of variables and provide some descriptive statistics of the variables used in this study. In Section 3 we present descriptive estimations from associating outcomes of children with those of parents, grandparents (income and education) and great-grandparents (education). In Section 4 we outline the simple Becker-Tomes model of intergenerational transmission and test it using data on education spanning four generations. Section 5 concludes. 


\section{Data and Descriptive Statistics}

Figure 1 shows a schematic overview of the data set consisting of information on individuals from four generations of the same family. The data set originally stems from the so called Malmö Study, a survey initiated in 1938 by a team of Swedish educational researchers. ${ }^{2}$ All pupils attending third grade (normally at age 10) in any school in the Malmö metropolitan area $(n=1,542)$ were part of the original survey and constitute the index generation, which is the second generation included in the data set. The original purpose was to analyze the correlation between social surroundings and cognitive ability. Hence, a host of family background information was collected, including parental earnings for several years and father's education. Over the years, the Malmö Study has been extended with information from both several rounds of follow-up surveys and register data. The last collection of data using questionnaires to the children initially sampled was conducted 55 years after the first survey, i.e., in $1993 .{ }^{3}$ By that time, most of the individuals had reached retirement age.

\footnotetext{
${ }^{2}$ The material was originally collected by Siver Hallgren and developed by Torsten Husén.

${ }^{3}$ In 1993, 38\% of the third and fourth generations still lived in Malmö, an additional 31\% lived elsewhere in the county of Skåne, which is where Malmö is situated, $8 \%$ lived in the county of Stockholm, and the rest were quite evenly spread out in the rest of Sweden.
} 
Figure 1 Schematic overview of the GEMS database.

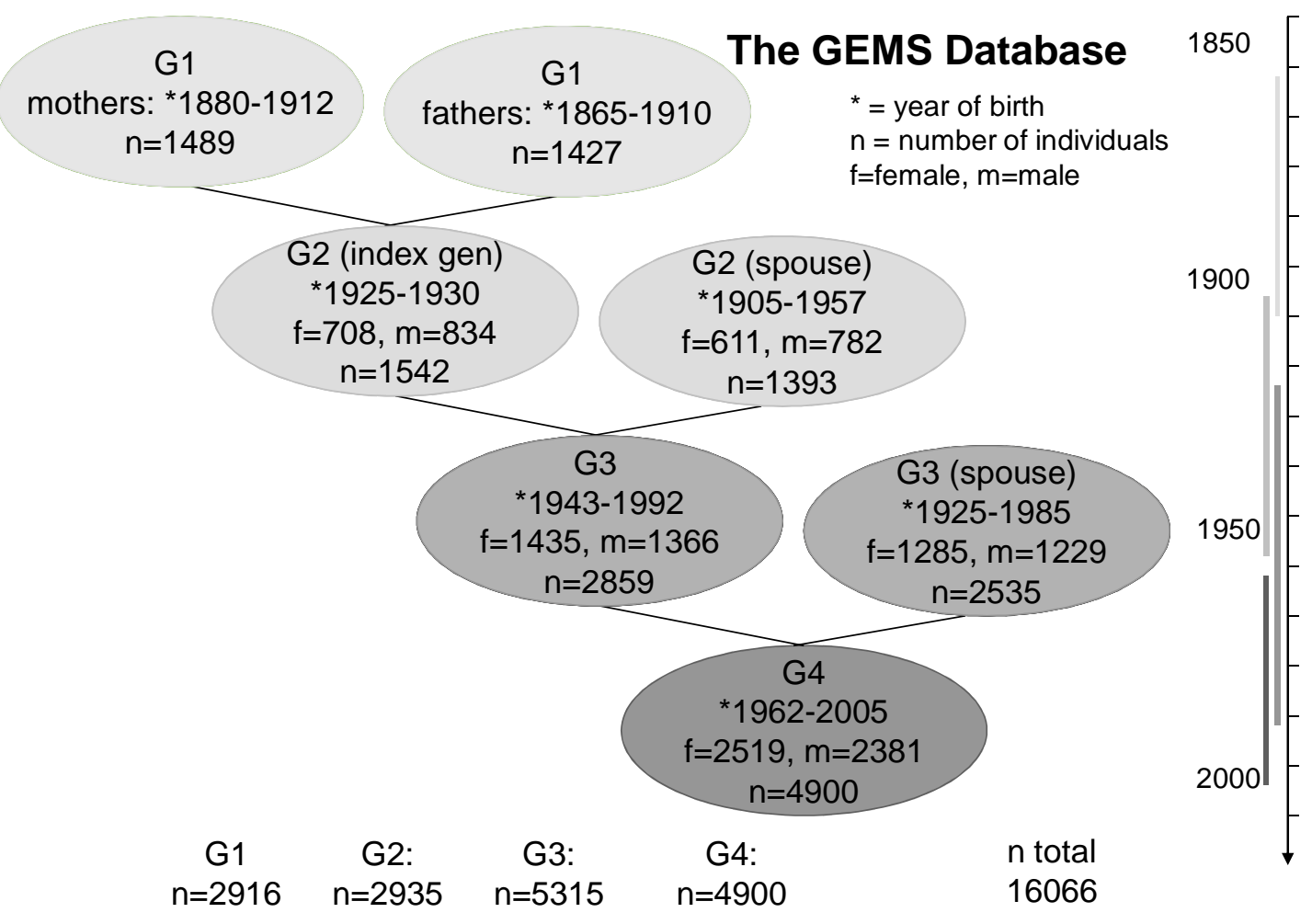


We have extended the data in several ways. We have added parish-register information on date of birth and death of the parents of the index generation. These parents constitute the first generation and were born between 1865 and 1912. We have also added register information on the second generation's children and grandchildren, as well as information on the spouses of the index generation, i.e., the second parent of these children and of the grandchildren. The resulting data set consists of information on four generations of the same families. The average birth year of the first generation (G1) is 1898 . The second generation $(\mathrm{G} 2)$, i.e. the index generation, is on average born in 1928; the third generation (G3), the children of the index generation, in 1956; and, finally, the fourth generation (G4), the grandchildren of the index generation, in 1985 .

In the Appendix we provide a short historical overview on Malmö and Sweden, focusing on the evolvement of institutions of likely importance to intergenerational mobility and the welfare state in Sweden during the relevant time period.

\subsection{Data on Educational Attainment}

The measure of educational attainments for the first generation was constructed by educational scientists and based on occupational classification of fathers from a survey in 1938. For the second to fourth generations, we have obtained data on educational attainments from the national education register. We mainly use data from 1985 for the second generation and from 2009 for the third and fourth generations. We transform the educational level measure for all generations into years of schooling based on the required number of years that has to be completed for each level.4 In order to avoid the problem that some children in the youngest generation may still have been in school at the time of data collection, we restrict the analysis of years of education to individuals who were at least 25 years of age in 2009, hence excluding those born after 1984.

So as to further increase the sample size for the analysis of education transmission, we construct a measure of whether or not an individual has completed an academic track in high school. This is a strong predictor of whether or not the individual continues on to higher

\footnotetext{
${ }^{4}$ With detailed information on completed level of education, we construct years of schooling as follows: 7 for (old) primary school, 9 for (new) compulsory schooling, 9.5 for (old) post-primary school (realskola), 11 for short high school, 12 for long high school, 14 for short university, 15.5 for long university, and 19 for a PhD. For those few individuals in the second generation where registry information for 1985 is missing, we use survey information from 1964. The education information from 1964 is in 6 levels, and probably of lower quality than for 1985 or 2009. The conversion is done by imputing years of schooling by regressing the years of schooling variable in 1985 on indicators for 1964 using all individuals for whom educational information is available in both years. For individuals in the third generation with missing education data, we instead draw on registry information from 2005 and 1985.
} 
education. We are then able to include children born until 1990. This increases the sample by about 35 percent.

\subsection{Measures of Lifetime Earnings}

Detailed earnings information allows us to construct measures of lifetime earnings for men in the first three generations. The fourth generation is not included in the analysis of earnings transmission since a large fraction of these individuals are too young to allow the construction of meaningful measures of lifetime earnings. Although the amount of earnings information differs across generations, available data from local and national tax registers cover the most important years of working life for all generations.

As regards the first generation, born on average in 1896, we have annual income information from local tax registers for the years 1929, 1933, 1937, 1938 and 1942. This implies that income is typically observed between ages 33 and 46 . The income measure is the sum of capital and labor income.

The second generation, most of whom were born in 1928 (the original Malmö population) or around 1928 (the other parent of the Malmö children), is covered from age 20 by at least 15 observations of annual earnings. The first observations of labor earnings stem from $1948 .^{5}$ From then on, there is information on earnings every third-fifth year until 1984. After 1984, we have annual observations of earnings.

As for the third generation, typically born in the mid-1950s, earnings data start in 1968. Like the second generation, information on earnings was collected every third-fifth year until 1984, after which there are annual observations.

We compute our earnings measure in two steps. First, using all earnings data available, ${ }^{6}$ we regress log-earnings on a cubic in birth year as well as year dummies, i.e., ${ }^{7}$

$$
\log (\text { earnings })_{i t}=\alpha+\gamma_{1} \text { birthyear }_{i}+\gamma_{2} \text { birthyear }_{i}^{2}+\gamma_{3} \text { birthyear }_{i}^{3}+\text { year }_{t}+\varepsilon_{i t}
$$

\footnotetext{
${ }^{5}$ Prior to 1968 , information on earnings is from local tax registers. As of 1968, the earnings data are from national registers. For individuals in the second generation who were not part of the original sample, i.e. the other parent of the third generation individuals, we have earnings information from 1948 if they cohabited with the Malmö-parent and from 1968 if they did not. ${ }^{6}$ We include all years for which we observe positive earnings, but exclude the observations when the individual was very young: 19 years of age for the first generation, 23 for the second and 27 for the third.

${ }^{7}$ This is the approach taken in e.g. Haider and Solon (2006) and Böhlmark and Lindquist ( 2006). Life-cycle bias should hence not be an issue here, as we have access to reasonable lifetime income measures for both parents and children. See also Lee and Solon (2009).
} 
Second, we obtain the residual for each individual-year cell it, and then compute the mean residual for each individual, i.e., the stable part of individual earnings, which is used as a measure of lifetime earnings.

\subsection{Descriptive Statistics}

We have information on educational attainments for 901 complete families, i.e., with data available on at least one individual in each generation, for four consecutive generations. ${ }^{8}$ For earnings, there are 730 families with earnings information available for one male member of the family in three consecutive generations. The main reason for attrition of families is that the individual has no children. There are, however, some individuals with missing information on earnings and/or education. Since earnings data are less informative for women in the earlier years, we restrict the analysis of earnings associations to sons, fathers and grandfathers. Note that for roughly half of the earnings sample, the male family member in the second generation (the father) is not the biological son of the male member of the family in the first generation (the grandfather), but is instead the son-in-law. This almost doubles the earnings sample. ${ }^{9}$

Table 1 reports descriptive statistics by generation and gender for the samples used in this study. We show statistics corresponding to the individuals in our estimation sample for education (four generations separated by gender) and earnings (three generations of men). The first column shows means and standard deviations for the fathers of the children in the index generation (generation 2). These 905 fathers were on average born in 1896 and had 7.3 years of schooling. The next two columns show descriptive statistics for those in the index generation (first interviewed in 1938 and typically born in 1928) as well as mothers and fathers of the children in the third generation. For this second generation typically born in 1928, there are 470 men who acquired 10.2 years of schooling and 435 women who acquired 9.5 years, on average. ${ }^{10}$

The earnings figures for men in the second and third generations pertain to sons and grandsons of the first generation of men as well as the male spouse of the daughters and

\footnotetext{
${ }^{8}$ We have 901 complete families with four generations when we include fourth generation children born un until 1990. For this sample, the education measure used for the fourth generation is academic high-school track. In order to obtain a meaningful measure of years of education for the fourth generation, we restrict the analysis to children born before 1986, resulting in 673 complete families.

${ }^{9}$ As a check, we also estimated transmission coefficients for education using these sample restrictions. The estimates are then very similar to those using only individuals who are biologically related across the four generations (which are the estimates reported in Table 2).

${ }^{10}$ On average, earnings increased from about SEK 86,000 (calculated in 1933) for the men in the first generation to SEK 311,000 (in 2000) for the men in the third generation, all expressed in 2010 prices.
} 
granddaughters belonging to the index and the next generations. Hence, the dispersion in the year-of-birth variable is much higher for the men in the index generation. The last two columns show descriptive statistics for the descendants of the three earlier generations who are old enough to be included in the regressions: 27 years in 2008 for earnings regressions; 25 years in 2009 for education estimations; and, finally, 19 years for the academic high-school track regressions. The average residual of log earnings, with means and standard deviations reported in the third row, summarizes the earnings measure actually used the in estimations. ${ }^{11}$

\footnotetext{
${ }^{11}$ These numbers are based on averages across years and are negative because those with fewer years of earnings
} data have lower earnings. 
Table 1 Descriptive statistics

\begin{tabular}{|c|c|c|c|c|c|c|c|}
\hline \multirow[b]{2}{*}{ Variable } & \multirow{2}{*}{$\begin{array}{c}\text { Generation } 1 \\
\text { (great-grandparents) } \\
\text { Great-grandfather } \\
\text { (1) }\end{array}$} & \multicolumn{2}{|c|}{$\begin{array}{l}\text { Generation } 2 \\
\text { (grandparents) }\end{array}$} & \multicolumn{2}{|c|}{$\begin{array}{l}\text { Generation } 3 \\
\text { (parents) }\end{array}$} & \multicolumn{2}{|c|}{$\begin{array}{l}\text { Generation } 4 \\
\text { (children) }\end{array}$} \\
\hline & & $\begin{array}{c}\text { Grandmother } \\
\text { (3) }\end{array}$ & $\begin{array}{l}\text { Grandfather } \\
(4)\end{array}$ & $\begin{array}{l}\text { Mother } \\
(5)\end{array}$ & $\begin{array}{l}\text { Father } \\
(6)\end{array}$ & $\begin{array}{l}\text { Daughter } \\
(7)\end{array}$ & $\begin{array}{c}\text { Son } \\
(8)\end{array}$ \\
\hline Years of schooling & $\begin{array}{l}7.30 \\
(1.60) \\
{[5.14]}\end{array}$ & $\begin{array}{c}9.53 \\
(2.67) \\
{[7.19]}\end{array}$ & $\begin{array}{l}10.15 \\
(2.96) \\
{[7.20]}\end{array}$ & $\begin{array}{l}12.05 \\
(2.47) \\
{[7.20]}\end{array}$ & $\begin{array}{l}12.11 \\
(2.59) \\
{[7.20]}\end{array}$ & $\begin{array}{l}12.95 \\
(1.98) \\
{[7.20]}\end{array}$ & $\begin{array}{l}12.42 \\
(2.13) \\
{[7.20]}\end{array}$ \\
\hline Academic high-school track & & & & & & $\begin{array}{c}0.55 \\
(0.50) \\
{[0.1]}\end{array}$ & $\begin{array}{c}0.44 \\
(0.50) \\
{[0.1]}\end{array}$ \\
\hline Average residual log earnings & $\begin{array}{c}-0.047 \\
(0.529) \\
{[-1.74,2.76]}\end{array}$ & & $\begin{array}{c}-0.018 \\
(0.637) \\
{[-2.71,2.26]}\end{array}$ & & $\begin{array}{c}-0.121 \\
(0.763) \\
{[-4.11,1.90]}\end{array}$ & & \\
\hline Year of birth (Education) & $\begin{array}{c}1896.12 \\
(7.20) \\
{[1859,1910]}\end{array}$ & $\begin{array}{c}1927.91 \\
(0.40) \\
{[1925,1930]}\end{array}$ & $\begin{array}{c}1927.87 \\
(0.40) \\
{[1926,1929]}\end{array}$ & $\begin{array}{c}1954.67 \\
(4.90) \\
{[1944,1970]}\end{array}$ & $\begin{array}{c}1954.53 \\
(4.46) \\
{[1943,1969]}\end{array}$ & $\begin{array}{c}1981.45 \\
(6.30) \\
{[1962,1990]}\end{array}$ & $\begin{array}{c}1981.49 \\
(6.35) \\
{[1962,1990]}\end{array}$ \\
\hline Year of birth (Earnings) & $\begin{array}{c}1895.70 \\
(7.48) \\
{[1865,1910]}\end{array}$ & & $\begin{array}{c}1926.73 \\
(3.27) \\
{[1888,1947]}\end{array}$ & & $\begin{array}{c}1956.69 \\
(5.54) \\
{[1943,1981]}\end{array}$ & & \\
\hline $\begin{array}{l}\text { Number of observations (Education) } \\
\text { Number of observations (Earnings) }\end{array}$ & $\begin{array}{l}905 \\
803\end{array}$ & 435 & $\begin{array}{c}470 \\
1,174\end{array}$ & 831 & $\begin{array}{c}722 \\
1,174\end{array}$ & 1,451 & 1,548 \\
\hline
\end{tabular}

Notes: The education numbers are calculated for the observations used in Table 2 (column 1) and Table 3 (columns 1-2) and the earnings numbers are calculated for the observations used in Table 5. The statistics for year of schooling for generation 4 is calculated for those born before 1985 (887 daughters and 936 sons). 


\section{Results: intergenerational Persistence in Educational Attainments and Earnings}

\subsection{Intergenerational Persistence in Educational Attainments}

The first set of results, the estimated transmission coefficients for education across the four generations under study, is shown in Table 2. All estimates are results from the bivariate regression model

$$
y_{t}=a+b y_{t-j}+u_{t}
$$

where $j \geq 1, y_{t}$ is the outcome of the child and $y_{t-j}$ is outcome of the parent $(j=1)$, grandparent $(j=2)$ or great-grandparent $(j=3)$. Since many members of the last generation had not yet completed their education at the date of data collection, we use completion of an academic track in secondary school as a proxy for educational aspiration. The last row in Table 2 reports linear probability model estimates of the relation between the probability of having completed an academic high-school track and earlier generations' educational attainments measured in years of education. The estimates (standard errors) are outcomes from regressions using unstandardized variables. We report standardized estimates in brackets.

Table 2 reveals two interesting results. First, there is a statistically significant estimate for the association between great-grandfather's educational attainment and that of greatgrandchildren. This result shows that there is a persistent correlation despite the fact that there are two generations, or on average 75 years, between the births of these generations. Second, the association between educational outcomes of the great-grandparent generation and the child generation, as well as between the great-grandparent generation and the parent generation is stronger than what would be expected if we were to predict these correlations based on the correlation between the adjacent generations involved.

The second result is easily obtained by multiplying the diagonal elements in Table 2 . For example, multiplying the coefficient estimate between the first and second generations, 0.607 , by that between the second and third, 0.281 , yields a prediction for the association between the first and third generations of 0.171 . By applying the delta method we obtain approximate 
bounds for the standard error of this prediction of between 0.023 and $0.033 .{ }^{12}$ These approximate bounds enable us to formally test and reject that the prediction obtained is equal to the coefficient between the first and the third generation, which was estimated to be 0.375 .

\footnotetext{
${ }^{12}$ The approximation of the variance for the product of $\beta_{1}$ and $\beta_{2}$, where $\beta_{1}$ is the estimate between generation one and two and $\beta_{2}$ is the estimate between generation two and three, is $\beta_{2}^{2} \sigma_{\beta_{1}}^{2}+\beta_{1}^{2} \sigma_{\beta_{2}}^{2}+2 \beta_{1} \beta_{2} \sigma_{\beta_{1} \beta_{2}}$. Since we are not able to estimate the covariance term $\sigma_{\beta_{1} \beta_{2}}$, we instead use the estimates of $\sigma_{\beta_{1}}, \sigma_{\beta_{2}}$ and the fact that the maximum correlation coefficient value is 1 to obtain an upper bound for $\sigma_{\beta_{1} \beta_{2}}$. The lower bound $\sigma_{\beta_{1} \beta_{2}}$ is set to 0 .
} 


\begin{tabular}{|c|c|c|c|}
\hline & $\begin{array}{c}\text { Years of Schooling - } \\
\text { great grandparent } \\
\text { (1) }\end{array}$ & $\begin{array}{c}\text { Years of Schooling } \\
\text { - grandparent } \\
\text { (2) }\end{array}$ & $\begin{array}{c}\text { Years of Schooling - } \\
\text { parent } \\
\text { (3) }\end{array}$ \\
\hline Years of Schooling - grandparent & $\begin{array}{c}0.607 * * * \\
(0.065) \\
{[0.334]} \\
N=905\end{array}$ & & \\
\hline Years of Schooling - parent & $\begin{array}{c}0.375 * * * \\
(0.043) \\
{[0.229]} \\
\mathrm{N}=1553\end{array}$ & $\begin{array}{c}0.281 * * * \\
(0.024) \\
{[0.312]} \\
\mathrm{N}=1553\end{array}$ & \\
\hline Years of Schooling - child & $\begin{array}{c}0.145 * * * \\
(0.046) \\
{[0.123]} \\
N=1823\end{array}$ & $\begin{array}{c}0.131 * * * \\
(0.023) \\
{[0.202]} \\
N=1823\end{array}$ & $\begin{array}{c}0.296 * * * \\
(0.021) \\
{[0.412]} \\
N=1823\end{array}$ \\
\hline Academic HS track $(=1)-$ child & $\begin{array}{c}0.032 * * * \\
(0.007) \\
{[0.104]} \\
\mathrm{N}=2999\end{array}$ & $\begin{array}{c}0.028 * * * \\
(0.004) \\
{[0.163]} \\
\mathrm{N}=2999\end{array}$ & $\begin{array}{c}0.066 * * * \\
(0.004) \\
{[0.343]} \\
\mathrm{N}=2999\end{array}$ \\
\hline
\end{tabular}

Notes: Each reported estimate is from a separate regression of the education of members of one generation on the education of members of an older generation. All regressions control for a quadratic in the birth year of the member of both generations. The reported standard errors (in parentheses) are clustered on families. Standardized estimates are reported in brackets.

Table 3 reports the results from estimations of the intergenerational transmission coefficients separately by gender of offspring and ancestor. The most striking feature of these estimates is that the intergenerational correlation in educational attainments seems to be independent of the gender of both ancestor and offspring. For example, the correlation between the first and third generations is almost the same for males and females in the first generation. 
Table 3 Matrix of estimated transmission coefficients across generations: Years of education

\begin{tabular}{|c|c|c|c|c|c|}
\hline & Great-grandfather & Grandmother & Grandfather & Mother & father \\
\hline Years of Schooling - grandmother & $\begin{array}{c}0.565 * * * \\
(0.076) \\
{[0.311]} \\
\mathrm{N}=435\end{array}$ & & & & \\
\hline Years of Schooling - grandfather & $\begin{array}{c}0.661 * * * \\
(0.118) \\
{[0.364]} \\
\mathrm{N}=470\end{array}$ & & & & \\
\hline Years of Schooling - mother & $\begin{array}{c}0.344 * * * \\
(0.049) \\
{[0.210]} \\
N=831\end{array}$ & $\begin{array}{c}0.287 * * * \\
(0.047) \\
{[0.319]} \\
\mathrm{N}=415\end{array}$ & $\begin{array}{c}0.273 * * * \\
(0.039) \\
{[0.303]} \\
N=416\end{array}$ & & \\
\hline Years of Schooling - father & $\begin{array}{c}0.409 * * * \\
(0.060) \\
{[0.250]} \\
\mathrm{N}=722\end{array}$ & $\begin{array}{c}0.322 * * * \\
(0.057) \\
{[0.357]} \\
\mathrm{N}=335\end{array}$ & $\begin{array}{c}0.249 * * * \\
(0.048) \\
{[0.277]} \\
\mathrm{N}=387\end{array}$ & & \\
\hline Years of Schooling - daughter & $\begin{array}{c}0.159 * * * \\
(0.062) \\
{[0.135]} \\
\mathrm{N}=887\end{array}$ & $\begin{array}{c}0.135 * * * \\
(0.043) \\
{[0.208]} \\
\mathrm{N}=461\end{array}$ & $\begin{array}{c}0.117 * * * \\
(0.040) \\
{[0.181]} \\
\mathrm{N}=426\end{array}$ & $\begin{array}{c}0.305 * * * \\
(0.039) \\
{[0.425]} \\
\mathrm{N}=556\end{array}$ & $\begin{array}{c}0.228 * * * \\
(0.041) \\
{[0.318]} \\
\mathrm{N}=331\end{array}$ \\
\hline Years of Schooling - son & $\begin{array}{c}0.133 * * \\
(0.052) \\
{[0.113]} \\
N=936\end{array}$ & $\begin{array}{c}0.118 * * * \\
(0.041) \\
{[0.183]} \\
N=483\end{array}$ & $\begin{array}{c}0.146 * * * \\
(0.042) \\
{[0.226]} \\
N=453\end{array}$ & $\begin{array}{c}0.306 * * * \\
(0.042) \\
{[0.426]} \\
N=521\end{array}$ & $\begin{array}{c}0.328 * * * \\
(0.035) \\
{[0.458]} \\
\mathrm{N}=886\end{array}$ \\
\hline Academic HS track - daughter & $\begin{array}{c}0.035 * * * \\
(0.009) \\
{[0.112]} \\
\mathrm{N}=1451\end{array}$ & $\begin{array}{c}0.022 * * * \\
(0.008) \\
{[0.129]} \\
\mathrm{N}=713\end{array}$ & $\begin{array}{c}0.030 * * * \\
(0.007) \\
{[0.172]} \\
\mathrm{N}=738\end{array}$ & $\begin{array}{c}0.069 * * * \\
(0.007) \\
{[0.358]} \\
\mathrm{N}=815\end{array}$ & $\begin{array}{c}0.055^{* * * *} \\
(0.008) \\
{[0.289]} \\
\mathrm{N}=636\end{array}$ \\
\hline Academic HS track - son & $\begin{array}{c}0.029 * * * \\
(0.010) \\
{[0.093]} \\
\mathrm{N}=1548\end{array}$ & $\begin{array}{c}0.030 * * * \\
(0.008) \\
{[0.176]} \\
N=747\end{array}$ & $\begin{array}{c}0.028 * * * \\
(0.007) \\
{[0.160]} \\
N=801\end{array}$ & $\begin{array}{c}0.066 * * * \\
(0.007) \\
{[0.343]} \\
N=829\end{array}$ & $\begin{array}{c}0.071 * * * * \\
(0.006) \\
{[0.368]} \\
N=719\end{array}$ \\
\hline
\end{tabular}

Notes: Each reported estimate is from a separate regression of the education of members of one generation on the education of members of an older generation. All regressions control for a quadratic in the birth year of the member of both generations. The reported standard errors (in parentheses) are clustered on families. Standardized estimates are reported in brackets. 
Changes in education distributions, changes in the meaning of a particular number of years of education over time and possible non-linearities in the transmission process are not fully captured in the linearly estimated transmission coefficients. We therefore compute intergenerational transmission probabilities across education categories and corresponding odds ratios. The results are reported in Tables $4 \mathrm{a}-4 \mathrm{~d}$. For each generation we define four levels of education, from compulsory to university education.

Transition probabilities and odds ratios confirm the main result from Table 2, namely that there is substantial persistence across generations in the education level attained. In particular, Table $4 \mathrm{c}$ shows that there is a much higher probability of an individual belonging to the same education level as his ancestor even after four generations than belonging to any other education category. In addition, these transition probabilities indicate a presence of nonlinearities: there is higher persistence in the upper end of the education distribution. Those with more than compulsory education in the first generation are on average between 49 and 67 percent more likely, compared to random assignment, to have university educated greatgrandchildren, whereas those with only compulsory schooling are only 3 percent more likely than random assignment to have great grandchildren with compulsory schooling.

Table 4a Education of children (generation 2) conditional on education of parents (generation 1), transition probabilities and odds ratios

\begin{tabular}{|c|c|c|c|c|c|c|}
\hline \multirow[b]{2}{*}{$\begin{array}{l}\text { Education of } \\
\text { parents } \\
\text { (generation 1) }\end{array}$} & & \multicolumn{4}{|c|}{ Education of children (generation 2) } & \multirow{2}{*}{$\begin{array}{c}\text { All } \\
\mathrm{P}_{\mathrm{i} .} \\
\text { Obs }_{\mathrm{i}}\end{array}$} \\
\hline & & Compulsory & $\begin{array}{c}\text { Post } \\
\text { compulsory: } \\
\text { short or } \\
\text { vocational }\end{array}$ & High school & University & \\
\hline Compulsory & $\begin{array}{c}P_{1 j} \\
P_{1 j} / P_{. j}\end{array}$ & $\begin{array}{l}0.50 \\
1.12\end{array}$ & $\begin{array}{l}0.32 \\
1.01\end{array}$ & $\begin{array}{l}0.14 \\
0.86\end{array}$ & $\begin{array}{l}0.04 \\
0.54\end{array}$ & $\begin{array}{l}0.85 \\
765\end{array}$ \\
\hline $\begin{array}{l}\text { Post compulsory: } \\
\text { Some vocational }\end{array}$ & $\begin{array}{r}\mathrm{P}_{2 \mathrm{j}} \\
\mathrm{P}_{2 \mathrm{j}} / \mathrm{P}_{\mathrm{j}}\end{array}$ & $\begin{array}{l}0.23 \\
0.50\end{array}$ & $\begin{array}{l}0.31 \\
0.99\end{array}$ & $\begin{array}{l}0.31 \\
1.85\end{array}$ & $\begin{array}{l}0.16 \\
2.19\end{array}$ & $\begin{array}{c}0.08 \\
75\end{array}$ \\
\hline $\begin{array}{l}\text { Post compulsory: } \\
\text { Academic (short) }\end{array}$ & $\begin{array}{c}\mathrm{P}_{3 \mathrm{i}} \\
\mathrm{P}_{3 \mathrm{j}} / \mathrm{P}_{\mathrm{j}}\end{array}$ & $\begin{array}{l}0.08 \\
0.18\end{array}$ & $\begin{array}{l}0.32 \\
1.04\end{array}$ & $\begin{array}{l}0.30 \\
1.79\end{array}$ & $\begin{array}{l}0.30 \\
4.08\end{array}$ & $\begin{array}{c}0.04 \\
37\end{array}$ \\
\hline $\begin{array}{l}\text { High school/ } \\
\text { University }\end{array}$ & $\begin{array}{r}\mathrm{P}_{4 \mathrm{j}} \\
\mathrm{P}_{4 \mathrm{j}} / \mathrm{P}_{\mathrm{j}}\end{array}$ & $\begin{array}{l}0.11 \\
0.24\end{array}$ & $\begin{array}{l}0.18 \\
0.58\end{array}$ & $\begin{array}{l}0.25 \\
1.51\end{array}$ & $\begin{array}{l}0.46 \\
6.37\end{array}$ & $\begin{array}{c}0.03 \\
28\end{array}$ \\
\hline All & $\begin{array}{c}P_{. j} \\
\text { Obs }_{. j}\end{array}$ & $\begin{array}{l}0.45 \\
408 \\
\end{array}$ & $\begin{array}{l}0.31 \\
281 \\
\end{array}$ & $\begin{array}{l}0.17 \\
150\end{array}$ & $\begin{array}{c}0.07 \\
66\end{array}$ & 905 \\
\hline
\end{tabular}

Notes: Education generation 1: compulsory max 8 years, post-compulsory: vocational 9 years, post-compulsory: academic (Realskola) 10 years, high school or university: min 12 years

Education generation 2: compulsory max 9 years, post-compulsory: short academic or vocational high-school track

(Realskola or short high-school track) 10-11 years, academic high-school track 12-14 years, university: min 15 years. 
Table $\mathbf{4 b}$ Education of grandchildren (generation 3 ) conditional on education of grandparents (generation 1), transition probabilities and odds ratios

\begin{tabular}{|c|c|c|c|c|c|c|}
\hline \multirow[b]{2}{*}{$\begin{array}{l}\text { Education of } \\
\text { grandparents } \\
\text { (generation 1) }\end{array}$} & & \multicolumn{4}{|c|}{ Education of grandchildren (generation 3) } & \multirow{2}{*}{$\begin{array}{c}\text { All } \\
\mathrm{P}_{\mathrm{i} .} \\
\mathrm{Obs}_{\mathrm{i}}\end{array}$} \\
\hline & & Compulsory & $\begin{array}{c}\text { Post } \\
\text { compulsory: } \\
\text { short or } \\
\text { vocational }\end{array}$ & High school & University & \\
\hline \multirow[t]{2}{*}{ Compulsory } & $\mathrm{P}_{1 \mathrm{j}}$ & 0.20 & 0.40 & 0.26 & 0.15 & 0.85 \\
\hline & $\mathrm{P}_{1 \mathrm{j}} / \mathrm{P}_{\mathrm{j}}$ & 1.08 & 1.09 & 0.98 & 0.79 & 1317 \\
\hline Post compulsory: & $P_{2 j}$ & 0.13 & 0.23 & 0.30 & 0.34 & 0.08 \\
\hline Some vocational & $\mathrm{P}_{2 \mathrm{i}} / \mathrm{P}_{\mathrm{i}}$ & 0.69 & 0.64 & 1.11 & 1.84 & 128 \\
\hline Post compulsory: & $\mathrm{P}_{3 \mathrm{j}}$ & 0.10 & 0.15 & 0.33 & 0.42 & 0.04 \\
\hline Academic (short) & $\mathrm{P}_{3 \mathrm{j}} / \mathrm{P}_{\mathrm{j}}$ & 0.55 & 0.41 & 1.24 & 2.23 & 60 \\
\hline High school/ & $\mathrm{P}_{4 \mathrm{i}}$ & 0.02 & 0.13 & 0.29 & 0.56 & 0.03 \\
\hline University & $\mathrm{P}_{4 \mathrm{j}} / \mathrm{P}_{\mathrm{j}}$ & 0.12 & 0.34 & 1.09 & 3.01 & 48 \\
\hline \multirow[t]{2}{*}{ All } & $P_{. j}$ & 0.18 & 0.37 & 0.27 & 0.19 & \\
\hline & $\mathrm{Obs}_{\mathrm{j}}$ & 280 & 567 & 416 & 290 & 1553 \\
\hline
\end{tabular}

Notes: Education generation 1: compulsory max 8 years, post-compulsory: vocational 9 years, post-compulsory: theoretical (Realskola) 10 years, high school or university: min 12 years.

Education generation 3: compulsory max 9 years, post-compulsory: short academic or vocational high-school track

(Realskola or short high-school) 10-11 years, academic high-school track, 12-14 years, university: min 15 years.

Table 4c Education of great-grandchildren (generation 4) conditional on education of great-grandparents (generation 1), transition probabilities and odds ratios. (families with 4th generation born before 1985)

\begin{tabular}{|c|c|c|c|c|c|c|}
\hline \multirow[b]{2}{*}{$\begin{array}{c}\text { Education of } \\
\text { great- } \\
\text { grandparents } \\
\text { (generation 1) }\end{array}$} & & \multicolumn{4}{|c|}{ Education of great-grandchildren (generation 4) } & \multirow{2}{*}{$\begin{array}{c}\text { All } \\
\text { Pi. } \\
\text { Obsi. }\end{array}$} \\
\hline & & Compulsory & $\begin{array}{l}\text { Post } \\
\text { compulsory: } \\
\text { short or } \\
\text { vocational }\end{array}$ & High school & University & \\
\hline Compulsory & $P 1 j$ & 0.10 & 0.16 & 0.50 & 0.24 & 0.89 \\
\hline & $\underset{\mathrm{j}}{\mathrm{P} 1 \mathrm{j} / \mathrm{P} .}$ & 1.03 & 1.05 & 1.01 & 0.93 & 1620 \\
\hline Post compulsory: & $\mathrm{P} 2 \mathrm{j}$ & 0.09 & 0.07 & 0.46 & 0.38 & 0.07 \\
\hline Some vocational & $\underset{\mathrm{j}}{\mathrm{P} 2 \mathrm{j} / \mathrm{P}}$ & 0.93 & 0.43 & 0.94 & 1.49 & 121 \\
\hline Post compulsory: & $\begin{array}{c}\mathrm{P} 3 \mathrm{j} \\
\mathrm{P} 3 \mathrm{j} / \mathrm{P}\end{array}$ & 0.04 & 0.13 & 0.40 & 0.43 & 0.03 \\
\hline Academic (short) & $\mathrm{j}$ & 0.43 & 0.82 & 0.82 & 1.67 & 47 \\
\hline High school/ & $\begin{array}{r}\mathrm{P} 4 \mathrm{j} \\
\mathrm{P} 4 \mathrm{j} / \mathrm{P} .\end{array}$ & 0.06 & 0.11 & 0.43 & 0.40 & 0.02 \\
\hline University & $\mathrm{j}$ & 0.58 & 0.74 & 0.87 & 1.57 & 35 \\
\hline All & $\begin{array}{c}\text { P.j } \\
\text { Obs.j }\end{array}$ & $\begin{array}{c}0.10 \\
179\end{array}$ & $\begin{array}{l}0.16 \\
283\end{array}$ & $\begin{array}{c}0.49 \\
897\end{array}$ & $\begin{array}{l}0.25 \\
464\end{array}$ & 1823 \\
\hline
\end{tabular}

Notes: Education generation 1: compulsory max 8 years, post-compulsory: vocational 9 years, post-compulsory: academic (Realskola) 10 years, high school or university: min 12 years.

Education generation 4: compulsory max 9 years, post-compulsory: short academic or vocational high-school track (Realskola or short high-school) 10-11 years, Academic high-school track 12-14 years, university: min 15 years. 
Table 4d Education of great-grandchildren (generation 4) conditional on education of great-grandparents (generation 1), transition probabilities and odds ratios. (families with 4th generation born before 1990 )

\begin{tabular}{|c|c|c|c|c|}
\hline \multirow[b]{2}{*}{$\begin{array}{l}\text { Education of } \\
\text { great- grandparents } \\
\text { (generation 1) }\end{array}$} & & \multicolumn{2}{|c|}{ Education of great-grandchildren (generation 4) } & \multirow{2}{*}{$\begin{array}{l}\text { All } \\
\mathrm{P}_{\mathrm{i} .} \\
\mathrm{Obs}_{\mathrm{i}}\end{array}$} \\
\hline & & $\begin{array}{c}\text { Compulsory or } \\
\text { vocational high-school } \\
\text { track }\end{array}$ & Academic high-school track & \\
\hline \multirow[t]{2}{*}{ Compulsory } & $P_{1 j}$ & 0.53 & 0.47 & 0.86 \\
\hline & $\mathrm{P}_{1 \mathrm{j}} / \mathrm{P}_{\mathrm{j}, \mathrm{j}}$ & 1.04 & 0.95 & 2567 \\
\hline Post compulsory: & $P_{2 j}$ & 0.40 & 0.60 & 0.08 \\
\hline Some vocational & $\mathrm{P}_{2 \mathrm{j}} / \mathrm{P}_{\mathrm{j}}$ & 0.79 & 1.22 & 238 \\
\hline Post compulsory: & $P_{3 j}$ & 0.38 & 0.62 & 0.04 \\
\hline Theoretical (short) & $\mathrm{P}_{3 j \mathrm{j}} / \mathrm{P}_{\mathrm{j}}$ & 0.75 & 1.26 & 111 \\
\hline High school/ & $\mathrm{P}_{4 \mathrm{j}}$ & 0.29 & 0.71 & 0.03 \\
\hline \multirow[t]{2}{*}{ University } & $\mathrm{P}_{4 \mathrm{j}} / \mathrm{P}_{\mathrm{j}}$ & 0.57 & 1.44 & 83 \\
\hline & & 0.51 & 0.49 & \\
\hline \multirow[t]{2}{*}{ All } & $P_{. j}$ & 1521 & 1478 & 2999 \\
\hline & $\mathrm{Obs}_{\mathrm{j}}$ & 0.53 & 0.47 & 0.86 \\
\hline
\end{tabular}

Notes: Education generation 1: compulsory max 8 years, post-compulsory: vocational 9 years, post-compulsory: theoretical (Realskola) 10 years, high school or university: min 12 years

Education generation 4: Compulsory or vocational high-school track, academic track measured at earliest age 19

\subsection{Intergenerational persistence in earnings}

Table 5 shows the estimates of intergenerational earnings mobility between the first and second generations, the second and third generations as well as between the first and third generations, respectively. Although Swedish society has undergone extensive and important changes in different dimensions between the most active period of the first generation born around 1900 and the third generation mostly born in the 1950s and 1960s, the elasticities in earnings between consecutive generations seem to be quite stable: 0.356 between the first and second generations and 0.303 between the second and third. The latter elasticity is only slightly larger compared to estimates in previous studies for Sweden for children born in similar years (see e.g. Björklund, Lindahl and Plug, 2006).

The results in Table 5 allow us to predict the earnings mobility between the first and third generations from the two two-generation mobility measures. This gives us a prediction of 0.108 , which is substantially lower than the estimate of 0.184 obtained from data. Again applying the bounding exercise for the delta method (as explained in footnote 11) gives an estimate of the standard error ranging from 0.020 to 0.027 . A $t$-test of equality between the predicted and the estimated three-generation mobility measure gives a $t$-statistic between 1.47 and 1.58 , i.e., indicating a marginally significant difference. 
Table 5 Matrix of estimated transition coefficients across generations: log earnings of male offspring regressed on log earnings of male ancestor

\begin{tabular}{|c|c|c|}
\hline \multirow{2}{*}{ Offspring } & \multicolumn{2}{|c|}{ Ancestor } \\
\hline & grandparent & Parent \\
\hline Log(Earnings $)$ - parent & $\begin{array}{c}0.356 * * * \\
(0.040) \\
{[0.307]} \\
\mathrm{N}=803\end{array}$ & \\
\hline Log(Earnings $)$ - child & $\begin{array}{c}0.184 * * * \\
(0.044) \\
{[0.141]} \\
\mathrm{N}=1174\end{array}$ & $\begin{array}{c}0.303 * * * \\
(0.043) \\
{[0.268]} \\
\mathrm{N}=1174\end{array}$ \\
\hline
\end{tabular}

Notes: Each reported estimate is from a separate regression of the son's residual log earnings on residual log earnings of the ancestor. The earnings measures are average residual log-earnings from a regression of log earnings on a cubic in birth year and year dummies (see section 2). The reported standard errors (in parentheses) are clustered on families. Standardized estimates are reported in brackets.

As in the case of education, it is interesting to explore a presence of non-linearities in the transmission of earnings across generations. We examine this by means of transition matrices. Table 6 shows transition matrices for income quintiles across generations. The first panel reports the transition probabilities between the first and second generations; the second panel the corresponding figures for the second and third generations; finally, the third panel shows the transitions between the first and third generations.

There is one result of particular interest revealed in Table 6: the persistence across two consecutive generations is higher at the higher end of the income distribution. The highest persistence in all of three panels is found for the fifth quintile, i.e. the top 20 percent of the earnings distribution. As many as 34 percent of the grandchildren of those in the fifth quintile remain at the very top of the income distribution. Interestingly, the persistence in this cell is almost as high when we compare grandfathers and grandsons (first and third generations) as when the grandsons are instead compared to their fathers (second and third generations). 
Table 6 Transition matrices: offspring earnings quintile conditional on ancestor's earnings quintile.

\begin{tabular}{|c|c|c|c|c|c|}
\hline \multirow{2}{*}{$\begin{array}{l}\text { Earnings } \\
\text { quintile of } \\
\text { ancestor } \\
\text { Grandfathers }\end{array}$} & \multicolumn{5}{|c|}{ Earnings quintile of offspring } \\
\hline & Q1 & $\mathrm{Q} 2$ & Q3 & Q4 & Q5 \\
\hline Q1 & 0.30 & 0.29 & 0.21 & 0.11 & 0.10 \\
\hline Q2 & 0.25 & 0.20 & 0.20 & 0.23 & 0.11 \\
\hline Q3 & 0.16 & 0.20 & 0.26 & 0.22 & 0.17 \\
\hline Q4 & 0.16 & 0.18 & 0.21 & 0.27 & 0.18 \\
\hline \multirow[t]{2}{*}{ Q5 } & 0.14 & 0.14 & 0.11 & 0.18 & 0.44 \\
\hline & \multicolumn{5}{|c|}{ Sons } \\
\hline Fathers & Q1 & Q2 & Q3 & Q4 & Q5 \\
\hline Q1 & 0.31 & 0.26 & 0.17 & 0.18 & 0.09 \\
\hline Q2 & 0.20 & 0.24 & 0.19 & 0.20 & 0.18 \\
\hline Q3 & 0.21 & 0.18 & 0.28 & 0.18 & 0.15 \\
\hline Q4 & 0.15 & 0.18 & 0.22 & 0.22 & 0.23 \\
\hline \multirow[t]{2}{*}{ Q5 } & 0.14 & 0.15 & 0.14 & 0.23 & 0.35 \\
\hline & \multicolumn{5}{|c|}{ Sons } \\
\hline Grandfathers & Q1 & Q2 & Q3 & Q4 & Q5 \\
\hline Q1 & 0.19 & 0.23 & 0.21 & 0.24 & 0.14 \\
\hline Q2 & 0.23 & 0.22 & 0.23 & 0.17 & 0.14 \\
\hline Q3 & 0.25 & 0.19 & 0.20 & 0.20 & 0.16 \\
\hline Q4 & 0.17 & 0.20 & 0.21 & 0.20 & 0.22 \\
\hline Q5 & 0.16 & 0.16 & 0.16 & 0.18 & 0.34 \\
\hline
\end{tabular}

Notes: Fathers and sons; 774 families

If we briefly summarize the results from our descriptive estimations, they point toward a surprisingly strong association between grandparental education/earnings and education/earnings of grandchildren, and between great-grandparental education and education of great-grandchildren. Hence, regression toward the mean takes longer time in Sweden than suggested by the comparatively low estimates of intergenerational persistence found for two consecutive generations. In addition, transition matrices reveal that there is higher persistence at the upper end of the education and income distributions. We also find that simply taking the square of the intergenerational elasticity does not give an accurate picture of what we find using children and grandparents, suggesting that the basic assumption that intergenerational transmission follows an AR(1) process does not hold. 


\section{Estimating the Becker-Tomes model of intergenerational transmission of human capital}

\subsection{The model and its predictions}

From the Becker-Tomes (BT) model of intergenerational human capital transmission follows that the earnings of a child is positively related to the earnings of the parent, the endowment of the child and an error term referred to as "market luck". The positive impact of parental earnings on the earnings of the child can be derived from utility maximization where parents optimize between own consumption and investment in children's human capital (as in Becker and Tomes, 1979) or because of the existence of borrowing constraints (as in Becker and Tomes, 1986). ${ }^{13}$

The model can be modified to explicitly describe the relationship for education instead of earnings. ${ }^{14}$ This result in a link between schooling for children and parent specified as:

$$
s_{t}=\alpha+\beta s_{t-1}+\rho e_{t-1}+u_{t},
$$

i.e., education $(s)$ of the child-generation $t$ is a linear additive function of education in the parental generation $t-1$, unobserved endowment or ability $(e)$ and an error term $(u)$ capturing any exogenous shocks affecting $s_{t}$. By construction, $u_{t}$ is uncorrelated with $e_{t-1}$ and $s_{t-1} \cdot \beta$ is expected to be positive because of positive returns to parental investments in human capital.

BT also postulates that transmission of endowments from one generation to the next can be described as an $\mathrm{AR}(1)$ process:

$$
e_{t}=a+\lambda e_{t-1}+v_{t}
$$

where the random error $v_{t}$ is assumed to be uncorrelated with $e_{t-1}, u_{t}$ and $s_{t-1}$. Note that endowments include not only genetically determined ability, but also culture and behavioral factors. ${ }^{15}$

An immediate implication of this model is that a bivariate regression of children's education on parent's education leads to an upward bias in the estimation of $\beta$, since those

\footnotetext{
${ }^{13}$ See also Solon for an alternative derivation.

${ }^{14}$ See Holmlund, Lindahl and Plug, 2008, Plug and Vijverberg, 2005, and Sauder, 2006.

${ }_{15}$ Plug and Vijverberg, 2003 attempts to decompose the endowment transmission, $\lambda$, into genetic and nongenetic parts using data on adoptees and their rearing parents. They find that $50-70 \%$ is genetically transmitted.
} 
with higher endowment also have higher education. This implication has received empirical support in several studies (see e.g. Holmlund, Lindahl and Plug, 2011). ${ }^{16}$

The BT model as, expressed in equation (3) and (4), does not allow for a direct effect of grandparents' education on the education of grandchildren. Grandparents affect the education of grandchildren only indirectly through the inheritance of endowments. In the presence of credit constraints, grandparents also influence grandchildren's education through their investment in the human capital of the parent generation.

We can use (3) and (4) to obtain: ${ }^{17}$

$$
s_{t}=\alpha^{\prime}+(\beta+\lambda) s_{t-1}-\beta \lambda s_{t-2}+\rho v_{t-1}+u_{t}-\lambda u_{t-1}
$$

The BT model, hence, implies a negative effect of grandparents' education on children's education conditional on parent's education. The intuition for this negative coefficient on $s_{t-2}$, is that high grandparental education, $s_{t-2}$, implies low parental endowment, $e_{t-1}$, for a given level of parental education, $s_{t-1}$. From (5) it is also clear that an OLS regression of children's outcome on parent's and grandparent's outcome generates biased estimates: the coefficient on parent's education, $\beta+\lambda$, is estimated with a negative bias and the coefficient on grandparents education, $-\beta \lambda$, is estimated with a positive bias. The reason is that a firstorder lagged version of (3) implies that $\operatorname{cov}\left(s_{t-1}, u_{t-1}\right)>0$. To get consistent estimates we therefore need an alternative approach.

The first attempt to estimate equation (5), addressing the endogeneity problem of parental education, is provided in Behrman and Taubman (1985). Using a sample of descendents of twins, they first estimate (5) with OLS and find that grandparent's education is insignificantly related to grandchildren's education. Their IV-estimation, using the education of the grandfather's twin brother as an instrument for father's education, yields a significantly positive estimate of the effect of grandparent's education on child outcomes. As a result, they conclude that they cannot find support for the prediction of the BT model.

A limitation of their study is, however, that the sample is only generalizable to a rather restrictive population consisting of the offspring of twins, in particular the offspring of white

\footnotetext{
${ }^{16}$ There is also some evidence that a bivariate regression of children's income on parent's income gives an overestimate of the causal intergenerational income effect (see Björklund, Lindahl, and Plug, 2006, and Lefgren, Lindquist and Sims, 2011)

${ }^{17}$ Equation (5) follows from equation (3) and (4) simply because the latter two equations constitute an AR(1) model with an autocorrelated error term, which can be rewritten as an $\operatorname{AR}(2)$ model, where the coefficient on the first lagged variable will be positive and the coefficient on the second lagged variable will be negative. Also, note that for the constant in equation (5) we have that $\alpha^{\prime}=\alpha(1-\lambda)+\rho a$.
} 
male twins who served in the military during WWII. Furthermore, although novel and creative, the IV approach makes the questionable assumption that the education of a twin has no impact on educational attainment of the co-twin's child. This would not hold if the twins, who are often close to one another as adults, influence each other's children.

An alternative approach is used in a study by Sauder (2006) on U.K. data. He finds positive impact of grandparent's education using OLS, but no effect using IV. The IV approach exploits i) two distinct schooling reforms that took place in 1947 and 1973 in the U.K. and ii) mothers' birth order as instruments for parent's and grandparent's education. However, both instruments are problematic. First, it is difficult to separate cohort effects from reform effects when a reform, as was the case here, is introduced simultaneously in the whole country. Second, birth-order may affect post-education outcomes also through other channels than educational attainment, as is found in Black, Devereux and Salvanes (2005).

Our approach, suggested already by Becker and Tomes, is to use great-grandparents education as an instrument for parent's education, in a regression of children's education on parent's and grandparent's education. The identifying assumption is that great-grandparent's education has no impact on great-grandchildren's education, over and above the impact through parent's and grandparent's education. This assumption necessarily holds in the simple Becker-Tomes model as expressed above. Since we have access to four generations of data for education, we can implement this strategy here.

\subsection{Empirical test}

Table 7 shows the results from regression of education of a child on the education of parents and grandparents. The first two columns show results for years of schooling as outcome variable and the last two columns show results for the probability of graduating from an academic high-school track. Columns 1 and 3 show results from OLS-regressions and columns 2 and 4 the IV-results. The lower panel of Table 7 shows the first stage results corresponding to the IV-estimates.

The results from both first stage regressions are highly significant and the $F$-statistics for education of great-grandparents is 30.9 in column 2 and 47.9 in column 4 . This suggests that we have strong instruments. Moving to the IV-estimates, we find that they are positive and not significantly different from the corresponding OLS-estimates. ${ }^{18}$ Since a 95 percent

\footnotetext{
${ }^{18}$ We have also checked for non-linear effects of schooling of ancestors in the OLS and IV regressions, but quadratic terms are never statistically different from zero.
} 
confidence interval covers a negative value of grandparents' education, we cannot reject the Becker-Tomes prediction of a negative coefficient. 
Table 7 OLS and IV regressions of children's education on parent's and grandparent's education

\begin{tabular}{|c|c|c|c|c|}
\hline & \multicolumn{2}{|c|}{ Years of Schooling } & \multicolumn{2}{|c|}{ Academic high-school track } \\
\hline & OLS & IV & OLS & IV \\
\hline Main equation: & \multicolumn{4}{|c|}{ Education of child } \\
\hline Schooling of parent & $\begin{array}{c}0.264 * * * \\
(0.023) \\
{[0.368]}\end{array}$ & $\begin{array}{c}0.234 \\
(0.196) \\
{[0.327]}\end{array}$ & $\begin{array}{c}0.060 * * * \\
(0.004) \\
{[0.311]}\end{array}$ & $\begin{array}{c}0.045 \\
(0.038) \\
{[0.236]}\end{array}$ \\
\hline Schooling of grandparent & $\begin{array}{c}0.060 * * * \\
(0.021) \\
{[0.092]}\end{array}$ & $\begin{array}{c}0.068 \\
(0.057) \\
{[0.105]}\end{array}$ & $\begin{array}{c}0.011^{* * *} \\
(0.004) \\
{[0.061]}\end{array}$ & $\begin{array}{c}0.015 \\
(0.011) \\
{[0.085]}\end{array}$ \\
\hline $\begin{array}{l}\text { Cluster } \\
\mathrm{N} \\
\mathrm{R} 2\end{array}$ & $\begin{array}{c}673 \\
1,823 \\
0.194\end{array}$ & $\begin{array}{c}673 \\
1,823 \\
0.194\end{array}$ & $\begin{array}{c}901 \\
2,999 \\
0.126\end{array}$ & $\begin{array}{c}901 \\
2,999 \\
0.122\end{array}$ \\
\hline First stage equation: & \multicolumn{4}{|c|}{ Schooling of parent } \\
\hline Schooling of grandparent & & $\begin{array}{c}0.241 * * * * \\
(0.023) \\
{[0.268]}\end{array}$ & & $\begin{array}{c}0.236 * * * \\
(0.017) \\
{[0.263]}\end{array}$ \\
\hline $\begin{array}{l}\text { Schooling of great- } \\
\text { grandparent }\end{array}$ & & $\begin{array}{c}0.224 * * * \\
(0.040) \\
{[0.137]}\end{array}$ & & $\begin{array}{c}0.203 * * * \\
(0.029) \\
{[0.124]}\end{array}$ \\
\hline $\begin{array}{l}\text { Cluster } \\
\mathrm{N} \\
\mathrm{R} 2\end{array}$ & & $\begin{array}{c}673 \\
1,823 \\
0.177\end{array}$ & & $\begin{array}{c}901 \\
2,999 \\
0.220\end{array}$ \\
\hline
\end{tabular}

Notes: standard errors are clustered at the family.

From the point estimates of the influence of parents and grandparents reported in Table 7, we get that either $\beta$ or $\lambda$, but not both, is greater than zero. As there is abundant and convincing evidence that genetic traits are positively transmitted across generations, we assume that the endowment transmission coefficient $\lambda$ is greater than zero. This would imply that $\beta$, the causal effect of parent's education on the education of the child, is negative. In fact, using the estimates in column 2 of Table $7, \beta+\lambda=0.234$ and $-\beta \lambda=0.068$ we can solve for $\beta$ and $\lambda$. This gives $\beta=-0.169$ and $\lambda=0.403$.

These estimates are, however, fairly imprecise and in order to investigate how large a positive value of $\beta$ that we can exclude with reasonable statistical confidence we use the delta method to obtain standard errors. Assuming independence of estimates of $\beta$ and $\lambda$, we get that 
the standard error for the estimate of $\beta$ is $0.127 .{ }^{19}$ Hence, a $95 \%$ confidence interval around our estimated $\beta$ would reject that the causal effect of parental education on the education of the child is larger than 0.08 .

This back of the envelope calculation suggests an estimate much smaller in magnitude than typical OLS-estimates, including the estimate of 0.296 reported in Table 2 of this paper, but more in line with recent estimates of the causal effect of education based on outcomes from compulsory school reforms, twins and adoption data (see Holmlund, Lindahl and Plug, 2011, for an overview). ${ }^{20}$

\section{Conclusions}

We have explored intergenerational transmission of economic status across adjacent and distant generations over the span of a century. Our data enable us to link great-grandparents born at the end of the nineteenth century to great-grandchildren who finished their education in the early twenty-first century. We estimate intergenerational correlations in educational attainments between these generations and income correlations between the first generation and their grandchildren. We use the well-known Becker-Tomes model on intergenerational transmission of human capital to estimate the causal effect of parental education on child outcomes, using educational attainments of the first generation as an instrumental variable.

We find striking persistence in economic outcomes across generations. There is significant correlation between the educational attainments of the first generation and their greatgrandchildren. This is also true for the intergenerational earnings correlation. Individuals in the highest earnings quintile are more than twice as likely to have grandchildren in the highest income quintile as the rest of the population. From the estimates of the intergenerational correlations in both educational attainments and earnings we can reject the validity of simple extrapolations from correlations between adjacent generations to more distant generations as suggested in elementary text books on labor economics, such as Borjas (2009). Our findings imply that the persistence of inequality across generations is stronger than we would expect from the numerous studies on mobility in earnings and educational attainments based on only

\footnotetext{
${ }^{19}$ The standard error for the estimate of $\beta, \sigma_{\beta}$, is obtained by solving the two-equation system $\sigma_{\beta}^{2}+\sigma_{\lambda}^{2}=0.196^{2}$ and $\lambda^{2} \sigma_{\beta}^{2}+(-\beta)^{2} \sigma_{\lambda}^{2}=0.057^{2}$.

${ }^{20}$ Some might argue that the most convincing evidence of intergenerational education effects comes from rolled out compulsory schooling reforms. Evidence for both Norway (Black, Devereux, and Salvanes, 2005b) and Sweden (Holmlund, Lindahl and Plug, 2011) suggest small local average treatment effects. An exception is Oreopoulos, Page and Huff Stevens (2003) who find large effects on the grade-repetition of children.
} 
two generations. We therefore conclude that intergenerational mean reversion takes longer time than we previously knew from numerous two-generation studies.

In the final part of the empirical analysis, we use the Becker-Tomes model to estimate the causal effect of parental education on the educational attainments of their children. Based on our results we cannot reject absence of a causal relation. This result suggests that intergenerational persistence in economic outcomes, which we found to be stronger than expected from previous two-generation studies, is generated in some other way. Aspects of family that are not measured in the data - such as genetic factors, family traditions and social networks - are possible candidates. 


\section{References}

Aaberge, R., M. Mogstad and V. Peragine (2010), "Measuring Long-term Inequality of Opportunity", Journal of Public Economics 95, 193-204.

Becker, G. S. and N. Tomes (1979), "An Equilibrium Theory of the Distribution of Income and Intergenerational Mobility”, Journal of Political Economy 87(6), 1153-89.

Becker, G. S. and N. Tomes (1986), "Human Capital and the Rise and Fall of Families" Journal of Labor Economics 4(3), S1-39.

Becker, G. S., K. M. Murphy, and R. Tamura (1990), "Human Capital, Fertility, and Economic Growth", Journal of Political Economy 98(5), S12-37.

Behrman, J. R. and P. Taubman (1985), "Intergenerational Earnings Mobility in the US and a Test of Becker's Intergenerational Endowments Model", Review of Economics and Statistics 67, 144-151.

Bentzel, R. (1952), Inkomstfördelningen i Sverige [The Income Distribution in Sweden], Stockholm: IUI.

Bisin A. and T. Verdier (2000), "Beyond the Melting Pot: Cultural Transmission, Marriage and the Evolution of Ethnic and Religious Traits", Quarterly Journal of Economics CXV, 955-88.

Björklund, A. and K. G. Salvanes (2011), "Education and Family Background: Mechanisms and Policies", Handbook in Economics of Education, Amsterdam: Elsevier, 201-247.

Björklund, A., L. Lindahl and M. J. Lindquist (2010), "What More Than Parental Income, Education and Occupation? An Exploration of What Swedish Siblings Get from Their Parents", The B.E. Journal of Economic Analysis \& Policy 10(1), article 102.

Björklund, A., M. Jäntti and R. E. Roemer (2012), "Equality of Opportunity and the Distribution of Long-Run Income in Sweden”, Social Choice and Welfare, forthcoming.

Björklund, A., M. Lindahl and E. Plug (2006), "The Origins of Intergenerational Associations: Lessons from Swedish Adoption Data", Quarterly Journal of Economics 121(3), 999-1028.

Black S., P. Devereux and K. G. Salvanes, (2005a), "The More the Merrier? The Effect of Family Size and Birth Order on Children's Education", Quarterly Journal of Economics 120(2), 669-700.

Black, S. and P. Devereux (2010), "Recent Developments in Intergenerational Mobility", in O. Ashenfelter and D. Card (eds.), Handbook of Labor Economics, Vol. 4B, Ch. 16, Amsterdam: Elsevier.

Black, S., P. Devereux and K. G. Salvanes (2005b), "Why the Apple Doesn't Fall Far: Understanding Intergenerational Transmission of Human Capital", American Economic Review 95(1), 437-449. 
Böhlmark, A. and M. J. Lindquist (2006), "Life-Cycle Variations in the Association between Current and Lifetime Income: Replication and Extension for Sweden", Journal of Labor Economics 24(4), 879-900.

Borjas, G. J. (2009), Labor Economics, 5th edition. New York: Irwin/McGraw-Hill.

Diamond, P. A. (1965), "National Debt in a Neoclassical Growth Model", American Economic Review, 55, 1126-1150.

Galor, O. and J. Zeira (1993), "Income Distribution and Macroeconomics", Review of Economic Studies 60(1), 35-52.

Haider, S. and G. Solon (2006), "Life-Cycle Variation in the Association between Current and Lifetime Earnings", American Economic Review 96(4), 1308-1320.

Holmlund, H., M. Lindahl and E. Plug (2008), “The Causal Effect of Parents' Schooling on Children's Schooling: A Comparison of Estimation Methods", IZA Discussion Paper 3630.

Holmlund, H., M. Lindahl and E. Plug (2011), “The Causal Effect of Parents' Schooling on Children's Schooling: A Comparison of Estimation Methods", Journal of Economic Literature 49(3), 614-650.

Lee, C. and G. Solon (2009), "Trends in Intergenerational Income Mobility", Review of Economics and Statistics 91(4), 766-772.

Lefgren, L., M Lindquist, and D. Sims, ""Rich Dad, Smart Dad: Decomposing the Intergenerational Transmission of Income," Mimeo, SOFI, Stockholm University, October 2011.

Maurin, E. (2002), "The Impact of Parental Income on Early Schooling Transitions: A Reexamination Using Data over Three Generations", Journal of Public Economics 85(3), 301-332.

Mulligan, C. B. (1997), Parental Priorities and Economic Inequality, Chicago: University of Chicago Press.

Oreopoulos, Philip, Marianne Page and Anne Huff Stevens. 2006. "The Intergenerational Effects of Compulsory Schooling.” Journal of Labor Economics, 24(4): 729-760.

Plug, E. and W. Vijverberg (2003), "Schooling, Family Background, and Adoption: Is it Nature or Is it Nurture", Journal of Political Economy 111(3), 611--41.

Plug, E. and W. Vijverberg (2005), "Does Family Income Matter for Schooling Outcomes? Using Adoptees as a Natural Experiment”, Economic Journal 115(506), 880-907.

Roemer, J. E. (1993), “A Pragmatic Theory of Responsibility for the Egalitarian Planner”, Philosophy \& Public Affairs 22, 146-166.

Sacerdote, B. (2004), "What Happens When We Randomly Assign Children to Families?", NBER Working Paper No. 10894.

Sacerdote, B. (2005), "Slavery and the Intergenerational Transmission of Human Capital", Review of Economics and Statistics 87(2), 217-234. 
Saez-Marti M. and A. Sjögren (2008), "Peers and Culture", Scandinavian Journal of Economics 110(1), 73-92.

Sauder, U. (2006), "Education Transmission across Three Generations - New Evidence from NCDS Data", Mimeo, University of Warwick.

Solon, G. (1999), "Intergenerational Mobility in the Labor Market", in O. Ashenfelter and D. Card (eds.), Handbook of Labor Economics, vol. 3, ch. 29, 1761-1800, Amsterdam: Elsevier.

Warren, J. R. and R. M. Hauser (1997), "Social Stratification across Three Generations: New Evidence from the Wisconsin Longitudinal Survey", American Sociological Review 62(4), $561-572$.

\section{Appendix: Institutional Background}

The four generations studied in this paper span a century during which Swedish society was transformed from early industrialization to present day welfare society. While subsidized childcare, generous child allowances, free schooling through high school, generous grants and loans for higher education, social security, unemployment benefits, free health care and pensions constitute today's welfare system, Malmö in the beginning of the $20^{\text {th }}$ century had some, but not all of these institutions in place, when the parents of the initially sampled index generation grew up.

Malmö is located in the southern part of Sweden. It was and is by population size Sweden's third city. At the beginning of the 20th century Malmö grew at a rapid pace and tripled its population from 61,000 to 192,000 between 1900 and 1950, compared to today's 300,000. Much of the population growth was a result of rapid urbanization. Malmö was early on one of the most industrialized cities in Sweden. When the original data collection of the Malmö study was initiated, in 1938, three large employers dominated. ${ }^{21}$ After 1960, an increasing fraction was employed within the public sector and by 1980, 20\% of the men and $50 \%$ of the women held public sector jobs.

In the early 20th century, Swedish compulsory schooling was only six years, but a seventh year of was introduced already in 1914 in Malmö. Yet, many children kept leaving school after six years. Seven years of schooling only become the norm around 1920 when a municipal grant was introduced to compensate poor families for the lost earnings during the seventh year of school. This grant existed until 1936 when compulsory schooling was extended to 7 years throughout Sweden. In the late 1930's almost a third of all Malmö

\footnotetext{
${ }^{21}$ Kockums, a shipbuilding company and mechanical workshop, with 2,300 employees; Skånska Cement, a construction company, with almost 2,000 employes; and Malmö strumpfabrik, a stocking factory, with more than 1,000 employees.
} 
children continued beyond compulsory schooling. School enrolment, was hence higher than in the rest of Sweden. Malmö was also the first large municipality to extend compulsory schooling to 9 years in 1962. Arguably, basic educational infrastructure was well developed and accessible already to the index-generation studied here.

Since the 1920's, loans to help finance higher education were in principle available to the tiny fraction of young people qualified to studying at Universities. In the late 1950's student loans were also made available for studies at the high school level. The present day generous grant and loans program for university students was introduced in 1964. Since then, credit constraints are arguably unlikely to play a role for higher education choices.

Although our sample is not a random sample from the Swedish population, Malmö was (and is) a fairly representative city in Sweden. This can be seen if we compare the earnings distribution for our first generation from Malmö (using our sample) with the earnings distribution for the entire county. To do this we use estimates of the earnings distribution obtained by Bentzel (1952), who used tax registers to construct measures of the Swedish income distribution. Figure 2 compares the earnings distribution of the first generation in our data in 1937 with those obtained by Bentzel for the years 1935 and 1945. It is interesting to note that the income distribution among the Malmö families does not deviate drastically from the national income distribution. 
Figure $2 \mathrm{~A}$ comparison of earnings distribution for the first generation in the Malmo data for 1937 with those obtained by Bentzel (1952) for Sweden in 1935 and 1945.

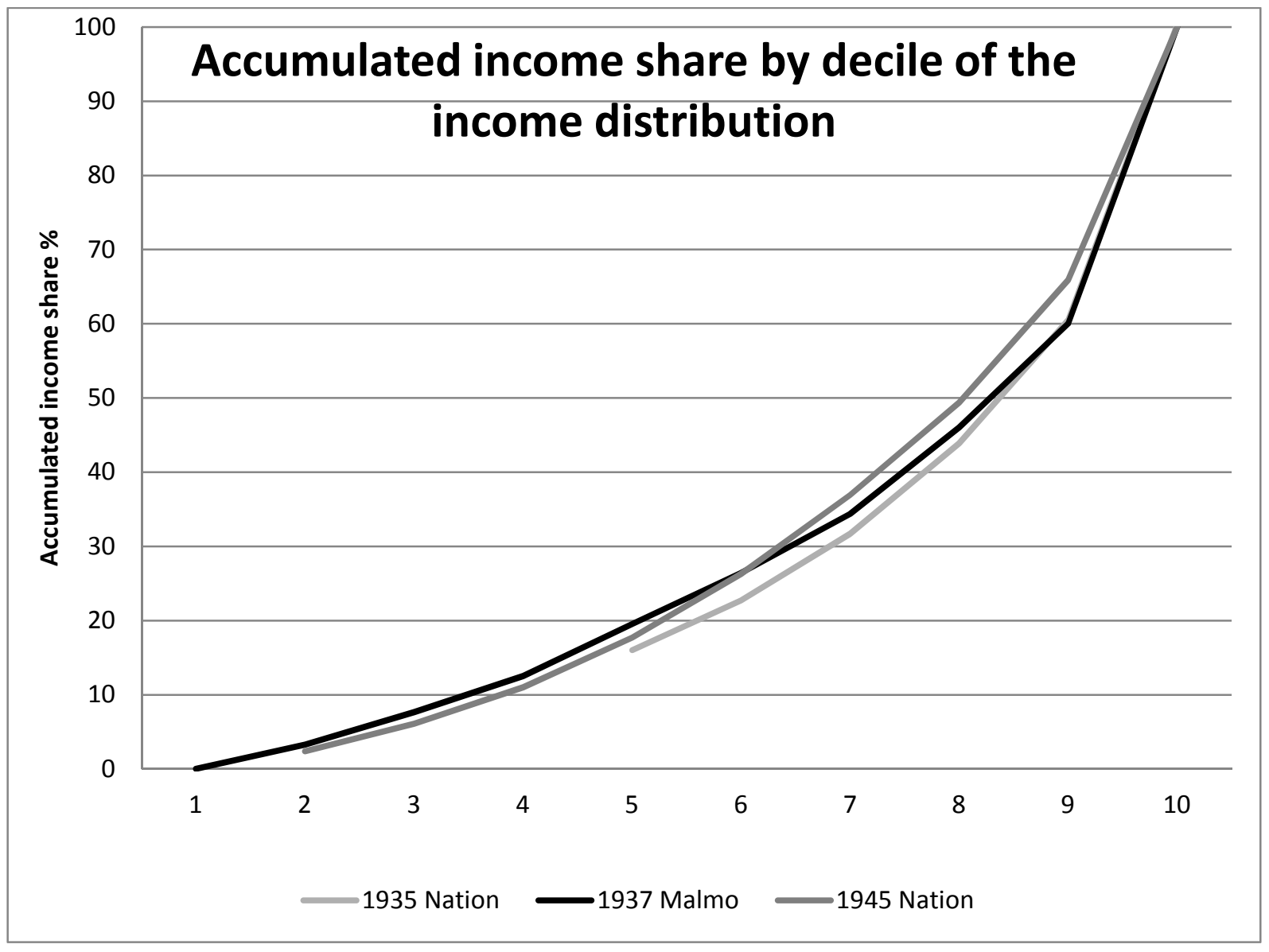

Source: Own computation based on Malmo data and Bentzel (1952). 